ISSN 2338-5324 (print)

ISSN 2442-7276 (online)

Online di http://jkp.fkep.unpad.ac.id

DOI : $10.24198 / \mathrm{jkp}$

\title{
Effect of Family Support Intervention towards Quality of Life with Elderly's Hypertension in Community
}

\author{
Raden Siti Maryam ${ }^{1}$, Yeti Resnayati ${ }^{1}$, Ni Made Riasmini ${ }^{1}$, Citra Windani Mambang Sari ${ }^{2}$ \\ ${ }^{1}$ Study Program D-III Nursing (Diploma) of Poltekkes Kemenkes Jakarta III, ${ }^{2}$ Faculty of Nursing, \\ Universitas Padjadjaran \\ Email: raden.maryam@poltekkesjakarta3.ac.id
}

Submitted: 16-01-2018 Accepted: 31-12-2018 Published: 31-12-2018

\begin{abstract}
The quality of life of the elderly is influenced by physical, psychological, social and environmental factors. These four factors desperately need family support as a support system for the elderly. This study aims to determine the effect of family support intervention on the quality of life of elderly hypertension in Community Area Cipayung Puskesmas East Jakarta. The research method used quasi-experiment with control group design. The sampling strategy used multistage random sampling with 30 samples for the intervention group and 30 for the control group. This study were implemented during four weeks. Statistical test using dependent t-test and independent t-test. There was a significant difference in the mean elderly quality of life with hypertension after the intervention of family support program in the intervention group compared with the control group $(M=93.67 \pm 6.08, p$-value 0.012$)$. In conclusion, this study showed that there were differences in mean older people quality of life with hypertension in the intervention group compared with the control group after the intervention of family support program. The resulting family support interventions can serve as the foundation for policy and health service providers in order to implement various interventions related to family empowerment to improve the quality of life older people with hypertension in the community.
\end{abstract}

Keywords: Family support intervention, hypertension for older people, quality of life of older people. 
Raden Siti Maryam : Effect of Family Support Intervention towards Quality of Life

\section{Introduction}

Multiple chronic diseases associated with the aging process can have an effect on the ability of the elderly to function independently so as to have an impact on their quality of life (Lueckenotte, 2000). Hypertension is the highest health problem in the elderly. Elderly with long suffering from hypertension certainly needs support from the family because it can affect their quality of life. This is in line with the research of Zulfitri (2006) that chronic diseases really need support from the family, especially emotional support, which can increase the enthusiasm and motivation of the elderly to behave and behave healthy.

National Basic Health Research (2013) shows the prevalence of hypertension in Indonesia obtained through measurement at age $>18$ years of $25.8 \%$ and will be higher in elderly. The prevalence of hypertension is a health problem for the highest elderly according to age group, which is $45.9 \%$ (5564 years); $57.6 \%$ (65-74 years); and 63.8\% (over 75 years) followed by arthritis and stroke.

Data of Puskesmas Kecamatan Cipayung (Community Health Center of Cipayung District) related to NCD (NonCommunicable Disease) Hypertension in July 2017 that was from 10 existing Puskesmas Kelurahan, Cipayung Community Health Center relatively had a greater number of hypertension patients than Kelurahan Bambu Apus. According to officers, Kelurahan Cipayung has a good record and complete as well as officers and health cadres are cooperative. The highest health problem data in the last 6 months from September 2016 was Hypertension and ARI. Blood pressure test results during Prolanis (Chronic Disease Management Program), a group of patients with hypertension on 12 September 2017 showed $30 \%$ of patients still have high blood pressure despite taking medication and following Posyandu activities regularly.

The higher the incidence of hypertension and the resulting impacts, require support from all parties, especially the family as a support system for clients. Family support conducted synergistically with community participation can improve the elderly's ability to overcome problems, besides generating new intervention strategies for sustainability in health care.

Family support is the assistance provided by other families that will provide physical and psychological comfort to people faced with stressful situations (Taylor, 2006). Someone feels the benefit of the aid received because it will give satisfaction. Some research results suggested there was a relationship between family support and quality of life of patients with Type 2 DM (Yusra, 2011). There was a relationship between family support and depression levels in the elderly where the higher the family support, the lower the depression level (Kristyaningsih, 2011). The same study from Herlinah (2013) stated there was a relationship between emotional support, reward, information and instrumental in the behavior of elderly in controlling hypertension. And information support was the dominant factor towards elderly's behavior in controlling hypertension.

Emotional support given by the family is positively related to quality of life while instrumental support can reduce well-being because it creates dependence on that support (Reinhardt, Boerner, \& Horowitz, 2006 in Riasmini, 2013). This is in accordance with the function of the family which is to give love and security, pay attention, fulfill financial needs, maintain relationships with family members and the community and provide care if the elderly are sick.

Based on research from Badriah and Jahar (2017), thephysicaland psychologicalchanges that parents with DM have experienced affect the family support they had received. Another study by Thanakwang (2015) suggests that emotional and instrumental support is greater received from family members and significantly anticipated support associated with a sense of psychological well-being of older parents. Results of research conducted by Xie, Peng, and Yang (2017), social support and positive psychological intervention should be established and introduced accordingly with the physical disabilities of parents, to protect them from depressive symptoms. Family support is needed for elderly to improve the quality of life because the elderly can be declared to have a good level of quality of life if they express the level 
Raden Siti Maryam : Effect of Family Support Intervention towards Quality of Life

of inner, physical, and social satisfaction, convenience, and happiness. At present, there is no specific study regarding the influence of family support interventions on the quality of life of elderly people with hypertension, especially in the community. So this is what underlies the authors to conduct research on the effect of family support intervention programs on the quality of life for elderly people with hypertension in the community working area of Cipayung Health Center. The aim of the study was to identify the influence of family support intervention on the quality of life of the elderly with hypertension.

\section{Method}

This research was a quasi-experiment with control group design. This study compared the group that implemented the family support intervention to a group with no family intervention as a control group. This design used two measurements, before and after the treatment. Population in this study were all elderly with hypertension who were in the community of Cipayung Sub-District Health Center in East Jakarta. The sampling strategy uses a multistage method cluster. Data on elderly hypertension were obtained from the Cipayung Sub-District Health Center where researchers took 1 village out of 10 existing villages with the most hypertensive patients and selected Cipayung Village. From Cipayung Village which consists of 8 RWs elected RW 01, 02, and 03 with the most hypertensive sufferers.

The number of samples used as the subject of the study was determined using the sample formula of the average difference in the two independent groups, namely 32 respondents for the intervention group and 32 for the control group. Sampling fulfilled the inclusion criteria of the elderly who were the age of the pre-elderly (45-59 years), the elderly (60 years and over), and living with the family (children, grandchildren, or relatives); have hypertension; able to communicate, read and write; and willing to be a respondent. The exclusion criteria were the elderly who had a total bedrest. The drop out criteria was disruption/having other utilities during the intervention; did not present at family training meeting; and did not do the post-test at the end of the study. The number of samples to the end of the study were 30 respondents in the intervention group and 30 respondents in the control group. Decreased number of samples (Drop Out) due to not doing post-test at the end of the study (there were 4 respondents).

Support interventions were carried out for approximately 4 meetings in 4 weeks, which were divided into the first week of the pretest, second week family support training in 1 day for 3 hours, week III observation of family support given, and week IV posttest. Elderly with hypertension pre-test at week I related to quality of life and family support given. And at the end of intervention in week IV will be reassessed (post-test). Pre-test and post-test contain family abilities related to knowledge, attitudes, and skills in supporting elderly people with hypertension. On the second week all families in the intervention group attended training on how to do hypertension treatment and other forms of family support. The family was given a guidebook "Forming Family Support to the Elderly with Hypertension" to facilitate understanding and implementation of family support. In third week the family checks out what forms of family support have been given to the elderly for approximately one week.

Ethical procedures are applied in this study where respondents are protected by selfdetermination and autonomy aspects where respondents have the freedom to determine whether they are willing or refuse to take research without coercion from any party by signing an informed consent; privacy where the confidentiality of respondents is maintained and only uses information from respondents for the purposes of this research; anonymity where the name of the respondent is only used in the process of conducting research; and confidentiality where the researcher maintains the confidentiality of the respondent's identity and the information provided is only used in research purposes. This research has received ethical approval with the number LB.02.01/KE/L/150/2017 from the Unit for the Study of the Ethics of Health Research BPPSDM Jakarta Health Ministry Polytechnic II. 
Raden Siti Maryam : Effect of Family Support Intervention towards Quality of Life

\section{Result}

In this section, we describe the characteristics of the elderly consisting of age, sex, education, suffering duration, taking prescribed medications, checking blood pressure, routine exercise and cholesterol examination results. The number of respondents in the intervention group was 30 elderly and in the control group 30 elderly. Table 1 shows that the intervention and control groups have almost the same characteristics, namely: the majority of the pre-elderly are 45-59 years old, female, and the majority are elementary school. Table 2 shows that the characteristics of the elderly in the two groups were almost the same in taking antihypertensive drugs that were prescribed and routinely controlled blood pressure. Whereas for the long time suffering from hypertension, in the intervention group the most at $1-5$ years and in the control group less than 1 year. Table 3 shows that in both groups most had done regular exercise and the results of cholesterol checks when most were abnormal (hypercholesterolemia).

Table 1 Distribution of Elderly Characteristics Based on Age, Gender, and Education

\begin{tabular}{|c|c|c|c|c|c|c|}
\hline \multirow[t]{2}{*}{ Variable } & \multicolumn{2}{|c|}{ Intervention Group } & \multicolumn{2}{|c|}{ Control Group } & \multicolumn{2}{|c|}{ Total } \\
\hline & $\mathbf{N}$ & $\%$ & $\mathbf{N}$ & $\%$ & $\mathbf{N}$ & $\%$ \\
\hline \multicolumn{7}{|l|}{ Age } \\
\hline $\begin{array}{l}\text { Pre-elderly } \\
\text { (45-59 years) }\end{array}$ & 20 & 66.7 & 14 & 46.7 & 34 & 56.7 \\
\hline $\begin{array}{l}\text { Elderly } \\
\text { ( } 60 \text { years and above) }\end{array}$ & 10 & 33.3 & 16 & 53.3 & 26 & 43.3 \\
\hline \multicolumn{7}{|l|}{ Gender } \\
\hline Male & 8 & 26.7 & 9 & 30 & 17 & 28.3 \\
\hline Female & 22 & 73.3 & 21 & 70 & 43 & 71.7 \\
\hline \multicolumn{7}{|l|}{ Education } \\
\hline Unschooling & 2 & 6.7 & 7 & 23.3 & 9 & 15 \\
\hline $\begin{array}{l}\text { Elementary (Primary) } \\
\text { School }\end{array}$ & 11 & 36.7 & 10 & 33.3 & 21 & 35 \\
\hline JHS & 9 & 30 & 8 & 26.7 & 17 & 28.3 \\
\hline SHS & 7 & 23.3 & 5 & 16.7 & 12 & 20 \\
\hline Academy/College & 1 & 3.3 & 0 & 0 & 1 & 1.7 \\
\hline
\end{tabular}

Table 2 Distribution of Elderly Characteristics Based on The Suffering Duration, Taking Routin Medication, and Checking Blood Pressure Control

\begin{tabular}{ccccccc}
\hline Variable & \multicolumn{2}{c}{ Intervention Group } & \multicolumn{2}{c}{ Control Group } & Total & \\
\cline { 2 - 6 } & $\mathbf{N}$ & $\mathbf{\%}$ & $\mathbf{N}$ & $\mathbf{\%}$ & $\mathbf{N}$ & $\%$ \\
\hline Suffering & & & & & & \\
duration & & 13.3 & 17 & 56.7 & 21 & 35 \\
1. $<$ 1 years & 4 & 60 & 8 & 26.7 & 26 & 43.3 \\
2. 1-5 years & 18 & 26.7 & 5 & 16.6 & 13 & 21.7 \\
3. $>$ 5 years & 8 & & & & & \\
Taking & & & & & & \\
prescription & & & & 73.3 & 49 & 81.7 \\
medication & 27 & 10 & 8 & 26.7 & 11 & 18.3 \\
1. Yes & 27 & & & & \\
2. No & 3 & &
\end{tabular}


Raden Siti Maryam : Effect of Family Support Intervention towards Quality of Life

\begin{tabular}{|c|c|c|c|c|c|c|}
\hline \multicolumn{7}{|c|}{$\begin{array}{l}\text { Controlling } \\
\text { blood } \\
\text { pressure }\end{array}$} \\
\hline $\begin{array}{l}\text { Regular } \\
\text { control }\end{array}$ & 26 & 86.7 & 18 & 60 & 44 & 73.3 \\
\hline $\begin{array}{l}\text { Irregular } \\
\text { control }\end{array}$ & 4 & 13.3 & 12 & 40 & 16 & 26.7 \\
\hline
\end{tabular}

Table 3 Distribution of Elderly Characteristics Based on Routine Exerciseand Cholesterol Examination Results

\begin{tabular}{lcccccc}
\hline \multirow{2}{*}{ Variable } & \multicolumn{2}{c}{ Intervention Group } & \multicolumn{2}{c}{ Control Group } & \multicolumn{2}{c}{ Total } \\
\cline { 2 - 7 } & $\mathbf{N}$ & $\mathbf{\%}$ & $\mathbf{N}$ & $\mathbf{\%}$ & $\mathbf{N}$ & $\mathbf{\%}$ \\
\hline Routine & & & & & & \\
Exercise & 19 & 63.3 & 11 & 36.7 & 30 & 50 \\
Yes & 11 & 36.7 & 19 & 63.3 & 30 & 50 \\
No & & & & & \\
Cholesterol & & & & & & \\
$\begin{array}{l}\text { Examination } \\
\text { Results }\end{array}$ & 10 & 33.3 & 9 & 36.7 & 19 & 31.7 \\
$\begin{array}{l}\text { Normal } \\
(<200 \mathrm{mg} / \mathrm{dl})\end{array}$ & 20 & 66.7 & 21 & 63.3 & 41 & 68.3 \\
Abnormal & & & & & &
\end{tabular}

The results of the equality test analysis on the characteristics of the elderly showed no difference in age ( $\mathrm{p}$ value 0.079$)$; gender ( $\mathrm{p}$ value 0.575 ); education ( $\mathrm{p}$ value 0.683 ); exercise regularly ( $\mathrm{p}$ value 1.000); Cholesterol examination results when ( $p$ value 0.067 ); and quality of life ( $\mathrm{p}$ value 0.068 ) between the intervention group and the control group.

The results of the analysis of the equality of knowledge, attitudes and family behavior regarding support given to elderly hypertension showed that there was no difference in knowledge, attitudes and family behavior regarding support given to elderly hypertension between the intervention group and the control group ( $\mathrm{p}$ value $1.000 ; 0.472$; 0.359 ).
The results of the analysis showed that there were significant differences in the average family attitudes and behavior after the family support intervention program in the intervention group compared to the control group ( $p$ value 0.027 and 0.004 ). This explains that family attitudes and behavior are better after a family support intervention program in the intervention group compared to the control group.

The effect of family support intervention program on the quality of life of elderly people with hypertension in both groups can be seen in table 5 where the $p$ value is $<0.05$. This explains that the accepted hypothesis means that there is a difference in the average quality of life of the elderly with hypertension

Table 4 Analysis of Family Abilities after Intervention Family Support between Groups

\begin{tabular}{lllccc}
\hline \multicolumn{1}{c}{ Variable } & \multicolumn{1}{c}{ Group } & N & Mean & SD & P Value \\
\hline Knowledge & Intervention & 30 & 6.10 & 2.45 & 0.911 \\
& Control & 30 & 6.03 & 2.14 & \\
Attitude & Intervention & 30 & 24.27 & 3.40 & 0.027 \\
& Control & 30 & 22.50 & 2.55 & \\
Behavior & Intervention & 30 & 24 & 4.83 & 0.004 \\
& Control & 30 & 20 & 5.36 & \\
\hline
\end{tabular}


Raden Siti Maryam : Effect of Family Support Intervention towards Quality of Life

Table 5 Description of the Quality of Life of The Elderly after The Family Support Intervention Program between Groups

\begin{tabular}{cccccc}
\hline Variable & Group & N & Mean & SD & P Value \\
\hline Quality of Life & Intervention & 30 & 93.67 & 6.08 & 0.012 \\
& Group & 30 & 88.50 & 9.07 & \\
\hline
\end{tabular}

after a family support intervention program or in other words the elderly feel satisfaction related to their quality of life after a family support intervention program is carried out.

\section{Discussion}

The results showed that there was a significant difference in mean of the quality of life of elderly with hypertension after the family support intervention program in the intervention group compared to the control group ( $p$-value 0.012). This explained that the quality of life of elderly with hypertension turned high after the family support intervention program or in other words, elderly felt satisfied related to the quality of life after the intervention. This supported the assertion that improving the quality of familyprovided care was one way to streamline the cost of treatment (Zarit, 2015).

The quality of life of the elderly includes the physical realm that consists of comfort, energy, fatigue and rest; psychosocial one that encompasses positive and negative feelings, self-esteem, body image and self-appearance; a degree of independence that embodies physical activity, drug dependency and work capacity; social relationship that involves personal relationships, social support, sexuality activities; the environment of the opportunity for elderly to obtain information; and the spiritual (Pangkahila, 2007). Family experience in caring for the elderly related to perceived cultural values of the family, illustrates that the elderly have a position in the family as parents who must be respected, valued and cared for well. Besides that, the elderly also have an important role in the family because they have advantages, have extensive experience so that their opinions are still needed in decision making and can be used as role models for their children (Riasmini, 2013).
Elderly with long suffering from hypertension certainly needs support from the family because it can affect their quality of life. Herlinah's research (2013) states that there is a relationship between emotional support, appreciation, information and instrumentals with the behavior of the elderly in controlling hypertension. And information support is the dominant factor in the behavior of the elderly in controlling hypertension. Social support from family and friends can improve the health of the elderly through various mechanisms including real support and emotional support (Fiori, Antonucci, \& Cortina, 2006 in Riasmini, 2013).

The family support intervention program that provided in the design of training on the family in caring for the elderly with hypertension had a significant relationship to improve the quality of life of the elderly. This was in accordance with the research that there was a significant relationship between emotional support, appreciation, and information with the quality of life of PLWHA. The final result of the multivariate analysis showed that the most dominant support was related to the quality of life of PLWHA (Agustanti, 2006).

This is in line with the statement that multiple chronic diseases associated with aging processes can have an influence on the ability of the elderly to function independently so as to have an impact on their quality of life (Lueckenotte, 2000). Elderly with a chronic illness desperately needs support from the family especially emotional support, which can increase the spirit and motivation of the elderly to show attitude and behave healthily (Zulfitri, 2006).

The family support intervention program that provided was part of the health promotion aspect to improve health and the quality of life to achieve a happy and useful old age; health services aspect to improve the quality of health services for elderly care; and the 
Raden Siti Maryam : Effect of Family Support Intervention towards Quality of Life

elderly nursing aspect aimed at maintaining the health and life spirits of the elderly by improving the promotive, preventive, and curative caring which were the components in supporting the quality of life of the elderly (Hardywinoto \& Setiabudhi, 2005). This was in line with Heller's (2015) study which stated that family support intervention provided benefits in improving elderly welfare and access to health care and satisfaction.

The emotional support provided by the family was positively related to the quality of life whereas instrumental support can decrease the well-being as it set up dependence on the support (Reinhardt, Boerner, \& Horowitz, 2006 in Riasmini, 2013). This was in line with the family function of providing love and security, giving attention, meeting financial needs, maintaining relationships with family members and the community. Families that support each other, a deliberative decisionmaking, a very close relationship and plenty of time to be together are a series of unity in a balanced family (Kaakinen, 2015). Results of research conducted by Xie, Peng, and Yang (2017), social support positive psychological intervention should be established.

\section{Conclusion}

Family support intervention program affected the quality of life of elderly people with hypertension in the intervention group compared to the control group. This can be seen in the difference in the average quality of life of the elderly with hypertension between the two groups. It is expected that the Puskesmas can improve and maintain the activities carried out during the Posyandu for Elderly or Posbindu PTM or Prolanis by providing counseling about family support given to the elderly with hypertension; monitoring and evaluating families with elderly people with hypertension through home visits; and implementing a family empowerment program with once a month training every RW. For further research, it is expected that the old family support intervention activities will be extended to 2 months and monitoring reading the guidebook with the checklist and using qualitative research designs to explore the experiences of families caring for elderly people with hypertension.

\section{References}

Agustanti, D. (2006). Hubungan dukungan sosial dengan kualitas hidup orang dengan HIV/AIDS (ODHA) di Kota Bandar Lampung. Tesis. FIK UI. Depok.

Badriah, S., \& Sahar, J. (2017). Family support in caring for older people with diabetes mellitus: A phenomenology study. Enferm Clin, 27(Suppl. Part I), 245-249.

Hardywinoto \& Setiabudhi, T. (2005). Panduan gerontology: Tinjauan dari berbagai aspek. Jakarta: Penerbit PT Gramedia Pustaka Utama.

Heller, T., Gibbon, H.M., \& Fisher, D. (2015). Caregiving and family support interventions: Crossing networks of aging and developmental disabilities. Intellect Dev Disabil, 53(5), 32945. doi:10.1352/19349556-53.5.329.

Herlinah, L., Wiarsih, W., \& Rekawati, E. (2013). Hubungan dukungan keluarga dengan perilaku lansia dalam pengendalian hipertensi. Jurnal Keperawatan Komunitas, 1(2), 108-115.

Kaakinen, J.R., Coehlo, D.P., Steele, R., Tabacco, A., \& Hanson, S.M.H. (2015). Family health care nursing. Theory, practice, and research $\left(5^{\text {th }}\right.$ Ed.). Philadelphia: F.A. Davis Company.

Kristyaningsih, D. (2011). Hubungan antara dukungan keluarga dengan tingkat depresi pada lansia. Jurnal Keperawatan, 1(1).

Lueckenotte, A.G. (2000). Gerontologic nursing ( $3^{\text {rd }}$ Ed.). St. Louis: Mosby Elsevier.

Pangkahila, W. (2007). Anti-aging medicine: Memperlambat penuaan meningkatkan kualitas hidup. Jakarta: Kompas Media Nusantara. 
Raden Siti Maryam : Effect of Family Support Intervention towards Quality of Life

Riasmini, M. (2013). Efektivitas model kelompok keluarga mandiri untuk meningkatkan kualitas hidup lanjut usia di masyarakat Wilayah DKI Jakarta. Disertasi. FIK UI. Depok.

Taylor, S.E. (2006). Health psychology $\left(6^{\text {th }}\right.$ Ed.). Singapore: Mc.Graw Hill Book Company.

Thanakwang, K. (2015). Family support, anticipated support, negative interaction, and psychological well-being of older parents in Thailand. Psychogeriatrics, 15, 171-178. doi:10.1111/psyg. 12107.

Xie, H., Peng, W., Yang, Y., Zhang D., Sun, Y., Wu, M., Zhang, J, ..., Su, Y. (2017). Social support as a mediator of physical disability and depressive symptoms in
Chinese elderly. Psychiatric Nursing. http:// dx.doi.org/10.1016/j.apnu.2017.11.012.

Yusra, A. (2011). Hubungan antara dukungan keluarga dengan kualitas hidup pasien DM tipe 2 di Poliklinik Penyakit Dalam RSUP Fatmawati Jakarta. Tesis. Tidak dipublikasikan.

Zarit, S.H., \& Reamy, A.M. (2015). Future directions in family and professional caregiving for the elderly. Gerontology, 59(2), 152-8. doi:10.1159/000342242.

Zulfitri, R. (2006). Hubungan dukungan keluarga dengan perilaku lanjut usia hipertensi dalam mengontrol kesehatannya di wilayah kerja Puskesmas Melur. Tesis. FIK UI. Depok. 